http://jmscr.igmpublication.org/home/

ISSN (e)-2347-176x ISSN (p) 2455-0450

crossref DOI: https://dx.doi.org/10.18535/jmscr/v7i11.56

Journal Of Medical Science And Clinical Research

\title{
A Study of Clinical Profile of Hyperglycemic Seizures in Tertiary Care Hospital
}

\author{
Authors \\ B Sai Sunil ${ }^{1^{*}}$, P.Aneesh ${ }^{2}$, Su. Charitha ${ }^{3}$, Dr S. Sreenivas. MD $^{4}$, \\ Dr Kankhamahalakshmi.MD \\ ${ }^{1,2,3}$ Post Graduate in Department of General Medicine), Andhra Medical College, Visakhapatnam \\ ${ }^{4}$ Professor in General Medicine, Andhramedical College, Visakhapatnam \\ ${ }^{5}$ Assistant Professor, General Medicine, Andhramedical College, Visakhapatnam \\ *Corresponding Author
}

B Sai Sunil

Adress: C/O K. Rammohan Rao, 17/59, Narshimhanagar Extension, Saligrampuram Post, Visakhapatnam, Andhrapradesh, Pin 530024, India

\section{Introduction}

Seizures associated with Non Ketotic Hyperglycaemia is now more commonly recognised new entity among adults, Hyperglycemic Seizure $\quad-$ a special Neuroendocrine syndrome most commonly due to Non Ketotic Hyperglycaemia has got its unique way of presentation, The clinical presentation of hyperglycaemic seizures associated with Non Ketotic Hyperglycaemia is studied only by few authors.

\section{Patient Selection}

The following patients were included:

1) Patients taken for this study includes Patients admitted with first Time convulsions who was later found to be Diabetic and whose

2) First admission Blood Sugar was in Hyperglycaemic level. 2. Known Diabetic patients who had focal neurological symptoms /Convulsions whose Blood sugar during convulsions showed Hyperglycaemic Seizure level.

3) Other Systemic problem patients who had convulsions during

Their hospital stay and showed Hyperglycaemic level of Blood glucose and later who were diagnosed as Diabetic patients.

\section{Aim of the Study}

1) To study the clinical profile of Hyperglycaemic Seizure (HGS).

2) To map out the age and sex incidence of Hyperglycaemic Seizure (HGS).

3) To analyse the commonly occurring type of seizure in Hyperglycaemic Seizure.

4) To evaluate the blood sugar levels with which Hyperglycaemic Seizure occurs.

5) To decide the level of serum osmolalilty with which commonly Hyperglycaemic Seizure occurs. 


\section{Results and Observation}

The total number of patients in this study was 50 . The study was done during the period of November 2017to may 2019

Age Distribution: The total number of patients included in the study was 50. Out of which 1 patient belong to the age group of less than 20 years. The youngest of them was 18 years old. 2 patients belong to age group of $30-39$ years. 10 patients belong to age group of $40-49$ years. 13 patients belong to age group of $50-59$ years. 24 patients belong to age group of above 60 years, 13 patients were below the age of 50 years. 37 patients were above the age of 50 years.

\section{Sex Distribution}

Out of 50 patients, 32 were male patients and 18 were female patients.

Percentage for total patients

1) First time admission with seizures 28 $(56 \%)$

2) Diabetes Mellitus with seizures 22 (44\%)

3) Out of 50 study patients, 28 patients had first time seizure without known Diabetes. 22 patients had diabetes with seizures.

\section{Analysis of Symptoms Sign of Hyperglycemia}

1. Focal seizures $27(54 \%)$

2. Focal Seizures with Altered Sensorium $6(12 \%)$

3. Focal Seizure with speech defect 2(4\%)

4. GTCS $6(12 \%)$.

5. GTCS with altered sensorium $3(6 \%)$

6. GTCS with Speech defect - APHASIA $2(4 \%)$

7. Epilepsia partialis continua $4(8 \%)$

Out of 50 patients, 35 patients had focal seizure and 11 patients had generalized tonic clonic seizure, 4 patients had epilepsia partialis continua features.

\section{Blood Glucose Analysis}

Among the 50 cases, 1 patient had blood sugar < $200 \mathrm{mg} / \mathrm{dl}$ and patients had blood sugar level was
$200-249 \mathrm{mg} / \mathrm{dl} .22$ patients had $250-299 \mathrm{mg} / \mathrm{dl}$. 15 patients had $300-349 \mathrm{mg} / \mathrm{dl}$. One patient had $350-399 \mathrm{mg} / \mathrm{dl}$. None of the patient had found blood glucose level above $400 \mathrm{mg} / \mathrm{dl}$.

\section{Osmolality Analysis}

Among 50 patients serum osmolality was normal in 5 patients. 45 Patients had hyper osmolality

CT scan Brain Analysis: Out of 50 study patients, 36 patients had normal CT scan and 14 had abnormal CT scan. In among 14 patients, 13 patients had infarct in the CT scan and 1 patient had cortical:

\section{EEG Analysis}

Out of 50 study patients, 42 patients had normal EEG and 8 patients had abnormal EEG. In among 8 patients, 2 patients had intermittent spike and sharp waves discharge on left parietal leads, and 4patients had bilateral epileptiform moves on right side and 2 patients had epileptiform moves on left side Atrophy

\section{Conclusion}

Hyperglycemic Seizures is a special neuro endocrine syndrome. Seizures can manifest as the first symptom of diabetes mellitus

Hyperglycaemic seizures can occur in Ketotic and Non Ketotic Hyperglycaemia but commonly in patients with non ketotic hyperglycaemia. Hyperglycaemic seizures is rarely associated with Diabetic Keto acidosis

Generalized tonic clonic seizure as the first manifestation of Non Ketotic hyperglycemia is found to be rare.

Hyperglycaemic seizures occurred commonly above the age of 50 years and the incidence is more in males. Most of the patients with hyperglycaemic seizures had blood glucose value between $250-300 \mathrm{mg} / \mathrm{dl}$.

In our study the mean blood glucose value was $277.3 \mathrm{mg} / \mathrm{dl}$ among patients with hyperglycaemic seizures. The minimum blood sugar value at which hyperglycaemic seizure occurred was 191 
$\mathrm{mg} / \mathrm{dl}$ and maximum blood sugar value at which hyperglycaemic seizures occurred was 398 $\mathrm{mg} / \mathrm{dl}$.

The osmolality was above the normal range in the maximum of $90 \%$ of cases. The CT scan brain evaluation showed normal without structural brain lesion in $72 \%$ of patients.

\section{References}

1. Joslin's Diabetes Mellitus $14^{\text {th }}$ edition by C. Ronald Khan, Gordon C. Weir.

2. Text book of Diabetes $2^{\text {nd }}$ edition by John and William.

3. Neurology in clinical practice $4^{\text {nd }}$ edition by Walter G. Bradley et al.

4. Harrison's Principles of internal medicine $20^{\text {th }}$ edition.

5. Engel and Pedley, Comprehensive test book of Epilepsy, Vol. 3, 2002.

6. Oxford Text Book of Nephrology, $3^{\text {rd }}$ edition, Vol. 1, 2004.

7. V. Seshiah, Head book of Diabetes, $2^{\text {nd }}$ edition, 2004.

8. Scherer C, Neurology, da Pr. Girrud CHV Di Jon, 2004.

9. KM Sabitha, A.S. Geneja, K.S. Vargose, A study seizure in Hyperglycemia patient, 2001.

10. Dr. J. J. Me Muray et al, Hyperglycemia non Ketotic focal epilepsy (DICA)

11. Rector WG, Herlong HF, Mosesh, Non Ketotic Hyperglycemia ballism Arck internal med.1982, 142: $154-5$.

12. Lammouchi T, Zoghlami F, Benshamia L, Griram, service de neuroogic tunisie.

13. Wasterlain CG, EPC, E. Medicine Lsost updated; March 6, 2002 (medicine)

14. Maccairo et al, Focal Seizures as manifestations of Hyperglycemia without Ketosis Neurology 1965 (15) 195 - 206.

15. Singh BM et al, Non Ketotic Hyperglycemia and Epilepsia partialis continua ACH: NEUROL,1977, 29, 187 190.
16. Grant C Warlow et al, Focal Epilepsy in Diabetic Non Ketotic Hyperglycemia, Br. Med J, 1985, 190,1204 - 05.

17. James C. Kolb, Robert Cox - Seizure in Hyperglycemia. 